\title{
Environmental Values and Response to Ecolabels Among International Visitors to New Zealand
}

\author{
John R. Fairweather and Crystal Maslin \\ Agribusiness and Economics Research Unit, P.O. Box 84, Lincoln \\ University, Canterbury, New Zealand
}

\author{
David G. Simmons \\ Environment, Society and Design Division, P.O. Box 84, Lincoln University, \\ Canterbury, New Zealand
}

\begin{abstract}
The research reported here documents the awareness of ecolabels among visitors to Christchurch, one important visitor destination in New Zealand. Around the world there is a growing debate about ecolabels and how visitors respond to them. We propose to inform this debate by studying the relationship between visitor response to ecolabels and their environment values. In interviews with 295 visitors to Christchurch it was found that only one-fifth recalled any place with ecolabels, and only $13 \%$ had ever heard of any tourism ecolabel. However, $33 \%$ of visitors had some experience of ecolabels. Data were cluster analysed to find that $61 \%$ of respondents expressed biocentric values and $39 \%$ expressed ambivalent values but not anthropocentric values towards nature. Further analysis of the data showed that the clusters had different responses on many dimensions of ecolabels. Biocentric visitors were concerned with the environment in which they travel, believed that ecolabels are needed in New Zealand, and said they would choose accommodation with an ecolabel. Their reports of their actions were consistent with their expressions of concern for the environment. Results suggest that many visitors will favourably receive ecolabel developments in New Zealand and that ecolabel development and use should be supported.
\end{abstract}

Keywords: ecolabels, tourism, New Zealand, environment, biocentric values

\section{Introduction}

The tourism industry, along with many other industries in contemporary society, is undergoing a change with respect to its relationship with the environment. One dimension of this change is the increase in nature-based, environmentally-oriented tourism usually known as ecotourism. Ecotourism involves references to sustainable tourism, triple bottom line reporting (social, economic, and environment), or the use of standards or plans to achieve improved environmental performance (Simmons, 1999). For Honey and Stewart (2002) ecotourism focuses on what travellers do plus the impact of this behaviour on both the environment and the people in the host country. In the case of New Zealand and following published standards, Higham et al. (2001: 9) define ecotourism as 'ecological sustainable tourism with a primary 
focus on experiencing natural areas that fosters environmental and cultural understanding, appreciation and conservation'. In many cases, ecotourism involves outdoor activities in a variety of settings, such as coastal areas or forests, designed to preserve the natural environment. The rhetoric of ecotourism suggests that tourism is becoming more environmentally sensitive or 'green', and visitors participating in such activities may be called 'green' visitors.

Along with developments in ecotourism there is an increase in the number of certifying agencies which provide environmental certification of some sort. Certification, demonstrated by an ecolabel, is meant to indicate the degree to which tourism businesses are, in fact, operating sustainably. We define a tourism ecolabel as any form of certification giving assurance that the tourist operation or activity is conducted according to a known standard that enhances the environment or at least minimises environmental impacts. Tourism ecolabels are beginning to manifest in New Zealand, but at this stage they are only in the earliest stages of development.

A number of important questions flow from the development of ecotourism, green visitors, and ecolabels. First, are visitors concerned about the environment in which they travel? A related question is: are visitors interested in environmentally sound management by tourism businesses? Second, what are the characteristics of those visitors who are so interested, what do they think about ecolabels, and how do they respond to them? Third, even if visitors express an interest in environmental performance, is this interest matched by actual behaviours, which may, but not necessarily, involve paying more for certified services? Finally, if tourism businesses use ecolabels but visitors are not interested or are still largely unaware of them, what interpretation of this can be made? Font (2001) and Dann (1997) make the suggestion that ecolabels are a product of businesses seeking a point of differentiation and note that certifying agencies push their label.

In this paper we report on market need for ecolabelling so as to usefully inform the development of sustainable tourism in New Zealand. Our research objectives were to document awareness of ecolabels and gauge demand for ecolabelled businesses and visitor activities. Our approach was to focus on the environmental values of visitors and study the relationship between these values and their response to ecolabels. In this way the research focuses mainly on the second question noted above by documenting the awareness of ecolabels among visitors to a major New Zealand destination, but it also makes a contribution to the other questions. We first review the literature on ecolabels to show that ecolabelling has already become an important part of the tourism industry internationally, but that visitor responses to ecolabels are varied and in many instances they are unaware of them. However, there are indications that visitors can have favourable attitudes towards the environment in which they travel and would therefore support environmentally friendly tourism and the use of ecolabels. Our results show that visitors to New Zealand, while not greatly aware of tourism-related ecolabels, express well-formed ideas about ecolabels. In particular, those who have biocentric environmental values have greatest interest in ecolabels and appear to be more likely to behave in ways that are environmentally friendly. 


\section{Ecolabelling and Visitors' Responses to Ecolabels}

Ecolabelling in tourism is becoming more common internationally. In a recent listing, Font (2001) describes over 70 schemes used throughout the world and Font (2002: 197) states that there are over 100 ecolabels for tourism, hospitality, and ecotourism. Similarly, Synergy (2000) assessed tourism certification and stated that there were more than 100 certification programmes or programmes offering a logo for some type of environmental achievement. These and other studies (Buckley, 2001; Spittler \& Haak, 2001) indicate that internationally there is a plethora of labels and concern over their quality and meaning. Closer to New Zealand, the Ecotourism Association of Australia in 1996 launched the National Ecotourism Accreditation Program (NEAP). By April 1997, there were 33 products ranging from accommodation and attractions to forests, coastal reefs and deserts (McArthur, 1997). NEAP is based on ecologically sustainable development principles and allows operators to be innovative and continually improve their practices. In New Zealand there is the emergence of Green Globe 21 with two businesses actually certified and three organisations (including one town) in the process of becoming certified in early 2004 (data from the Green Globe 21 website).

In contrast, while certification schemes have flourished, visitors' responses to ecolabels have been muted. Hamele (2002: 207) states that for Europe, ' ... studies have found that the vast majority of holidaymakers are unaware of the existence of the environment certification schemes in the tourism sector'. Wood and Halpenny (2001) argue that issues of sustainability do not figure in visitors' decision making, despite research showing that consumers are concerned about the impact of travel and tourism on the environment while indicating a growing willingness to pay for a more sustainable product. They believe that many visitors are unaware of certification programmes, yet stakeholders consulted during their research said that consumer demand will be the key to encouraging business to join certification programmes.

The literature is suggesting that while there are many ecolabels, visitors themselves may not be engaging with this development. This development runs counter to the idea that certification will allow visitors to favour and select sustainably run businesses which will therefore prosper, encouraging those that do not to either change or exit from the industry. This process would therefore ensure that tourism becomes increasingly sustainable. Lack of response to ecolabels would seem to jeopardise this development. But why is there a lack of response to ecolabels? Perhaps it is because visitors are not genuinely concerned about the environment in which they travel or do not really have any interest in the sustainability of tourism. Perhaps visitors may not even have environmental values or sympathies which would be necessary for them to engage with ecolabels?

Some support for this view can be found in Lubbert (2001) who surveyed 670 visitors in Germany to show that the most important attribute of an ecolabel was the information it provided, and in allowing the comparison of similar products. Environmental protection played a minor role in visitor decision making. Results from in-depth interviews showed that individual visitors did not feel responsible for the environment in a holiday destination and consequently were 
not interested in management systems that addressed environment issues. Visitors were interested in current environment conditions, not the process of achieving standards. In contrast, Honey (2002:363) reports that studies in several European countries showed that visitors were concerned about environment conditions in the destinations they chose. Further, Honey (2002: 364) reports studies by Tearfund which show consumer demand for a more ethical tourism industry and that they are willing to pay for it. Nielson et al. (1995) (an Australian conference paper cited in Issvardis (2001)) sampled nature-based tourist attitudes towards certification, and their results showed strong support for an ecotourism programme that accurately identified those operators committed to the principles of ecotourism. In New Zealand, Higham et al., (2001: 13-14) examined environmental values among 967 visitors to 12 ecotourism places selected, using 14 criteria to represent the diversity of places available. Over threequarters of the visitors made a positive assessment of the environmental performance of the ecotourism places, while only $6 \%$ reported an unfavourable experience. On balance then it seems safe to conclude that some visitors are concerned about the environment in which they travel. It follows that they may want businesses to operate in sustainable ways and use ecolabels to indicate this. Accordingly, it seems plausible to expect that visitors concerned about the environment would find ecolabels useful.

Support for this position is provided by Khan (2003) who reports on the service quality expectations of ecotourists by developing the ECOSERV scale and applying it to a random sample of ecotourists in the US. Her aim was to see if ecotourists have distinctive service quality expectations compared with mass tourists. Factor analysis of results found six dimensions, the first and most important of which was 'ecotangibles', indicating that ecotourists expected environmentally friendly services with minimum strain on the environment. The second most important dimension was 'assurance', so that ecotourists achieved a feeling of trust and confidence by being provided with appropriate information. Kahn suggests a range of environmentally friendly measures that can be implemented to satisfy the service quality expectation of ecotourists (including facilities harmonious to nature, equipment that upgrades environment performance, recycling) and notes that 'Management should ensure that the services offered to the customers in promotional activities are delivered as promised' (Khan, 2003: 121). These results suggest that ecolabels would be useful to ecotourists.

Concern for the environment in which visitors travel does not necessarily translate into environmentally friendly behaviours, particularly those that are consistent with high environmental standards. For example, concern about air pollution does not stop people using cars or flying to destinations, thereby generating greenhouse gases. In the case of New Zealand, flying generates significant quantities of greenhouse gases (Becken, 2002). Further, if any green product costs more, is inferior, involves more effort or does not satisfy consumer needs, then environmental values are likely to be of little consequence in consumer decision making (Sharpley, 2001: 45). Willingness to pay for environment performance or certification has been assessed. Bergin and Jago (1999) showed that customers were supportive of certification but would not necessarily purchase an accredited product over a non-accredited product. In contrast, Wight (2001) (citing 
Cook et al., 1992) reported that 'green' travellers were willing to spend on average $8 \%$ more for travel services and accommodation provided by environmentally responsible operators. They were more willing to pay for an eco-aware company than the average traveller. Further, many (85\%) were aware that their visit may disturb nature. Despite these supportive results it remains the case, however, that reports of willingness to pay may not translate into actual payments of a premium. Further, visitors may be quite unwilling to change travel behaviour to achieve environment benefits, especially if they believe that it would curtail their enjoyment or run counter to their travel goals.

To sum up, there seems to be genuine concern from visitors about the environment in which they travel but at the same time there appears to be lack of response to ecolabels. It seems plausible to expect environmentally sensitive visitors to be responsive to ecolabels and this lack of response appears to be an anomaly. Why is there lack of response? Perhaps in part this is due to poor marketing or presentation of ecolabels. We know there are many labels and they may cause confusion and prevent response. Perhaps in part the anomaly is because their concern for the environment is superficial. If so, greater attention needs to be given to visitors' environment values and in defining them. Available research on this topic shows mixed results: in Australia, Ryan and Harvey (2000) found that there was no relationship between environment values and attitudes or behaviours relating to crocodiles as part of a wildlife tourist attraction. In contrast, Luzar et al. (1995) found that environmental values did explain participation in Louisiana ecotourism. One promising line of exporation is to consider in more detail visitors' environment values. Studies to date may have been limited by assuming that visitors are relatively uniform in their environmental values and this may account for the lukewarm response to ecolabels. Perhaps visitors with strong environmental values are more disposed to ecolabels? We propose to explore this possibility by documenting the link between visitor response to ecolabels and their environment values.

The research reported here draws on a well-established technique in the environmental literature to assess environment values. The environmental literature demonstrates how fundamental value orientations can be assessed using response to statements about nature. Indeed, 'green' consumers who have preferences for goods and services that convey environmental concern are commonly identified for marketing purposes (Beckmann, 1999). Research to date has documented how people express 'anthropocentric' or 'biocentric' values (Dunlap et al., 2000) and these concepts have been applied in a variety of settings (such as forestry (McFarlane \& Boxall, 2000) and conservation (Vaske \& Donelly, 1999)). It is generally assumed that people with anthropocentric values are comfortable with using nature for economic or social benefits. In contrast, people with biocentric values are more cautious about use of nature and grant to nature intrinsic values, often seeing that it needs protecting from use. We expected to find both sets of values among visitors and hypothesised that visitors with biocentric values would be favourably disposed to the use of ecolabels. In addition, by further investigation and exploratory analysis, our intention is to identify differences between the groups in terms of dimensions such as demographic characteristics (gender, age, etc.), planned visitor activities and 
perceptions of the environment. Further, we expect that biocentric visitors will be more inclined to behave in ways that are sympathetic with the environment.

\section{Method}

During the period from 28 September to 23 November 2002 we collected data from a sample of visitors to Christchurch, the main city in the South Island of New Zealand and a major gateway for visitors who seek a wide range of attractions and activities. Interviews were conducted at four locations in Christchurch which attract significant flows of visitors: Cathedral Square, the Arts Centre, the Botanic Gardens and the outdoor area of City Mall on Cashel Street. The survey was part of a broader study of the economic, social and environmental effects of tourism on Christchurch (Simmons et al., 2003).

Quota sampling was used to match the characteristics of the sample of 295 visitors with known characteristics of all overseas and domestic visitors as indicated by official tourism statistics (International Visitor Survey and Domestic Tourism Monitor). Country of origin was used as the primary matching characteristic. However, the country of origin of the actual sample did not closely match the characteristics from the official statistics. While $60 \%$ of all visitors to Christchurch are domestic visitors our sample contained only $9 \%$. This was due to the location of the sampling sites at inner city visitor attractions typically frequented by international visitors but not by domestic visitors. In effect the sample best represents international visitors. Table 1 shows for all the international visitors in the sample their country of origin and compares it with official data. The sample has higher proportions of UK and other European visitors and lower proportions of Australians and Asians. Care should be taken in any attempt at generalising from the results of this sample. However, the sample does include all the major groups and is suitable for exploring environment attitudes and possible links to attitudes towards ecolabels.

The questionnaire started with the definition of an ecolabel: 'An ecolabel gives assurance that the tourist operation or activity (1) enhances the environment or (2) minimises environmental impacts'. This definition was read out to the respondent at the beginning of the interview. The questionnaire then included a basic question about experiences of ecolabels. The first topic under ecolabels was awareness of ecolabels. The second topic was their necessity in New Zealand. The third topic examined if the presence of an ecolabel would influence choice of accommodation and willingness to pay. There were two questions asking for a score from 1 to 10 on their opinion about the importance for Christchurch to manage its environment in a sustainable way, and their rating for actual environmental management. One question covered the importance of certification of environmental standards. The questionnaire then focused on environmental values and ecological awareness using eight questions taken from Dunlap et al. (2000) which have been shown to identify environmental values. Visitors were then asked to rate five statements about their environmental behaviours while travelling, derived in part from Higham et al., (2001), and whether they would participate in a tree planting scheme to help offset greenhouse gas emissions. The questionnaire also included questions relating to another topic of research in the tourism programme at Lincoln University; consequently space was limited and 
Table 1 Nationality for the sample compared with International Visitor Survey data (percentages)

\begin{tabular}{|l|c|c|}
\hline Nationality & Sample & IVS \\
\hline Australia & 20 & 29 \\
\hline UK & 25 & 12 \\
\hline Other Europe & 23 & 5 \\
\hline N. America & 15 & 12 \\
\hline Asia & 12 & 25 \\
\hline Other & 5 & 16 \\
\hline Total & 100 & 99 \\
\hline
\end{tabular}

there was no scope for asking additional questions on expenditure, accommodation or activities. The final section of the questionnaire recorded basic demographic data.

One potential weakness of this study must be noted. There is not a direct link between attitudes and behaviours, and respondents may have agreed with ecolabel concepts in principle but may not be following them in practice. Just because they say ecolabels are important does not mean that they would select accommodation, for example, that had an ecolabel if it cost more. In addition, we concede that there are a number of well-known studies that question the making of predictions of behaviour from attitude measures (e.g. La Piere, 1934; Wicker, 1969). However, more recent reviews of applications of Ajzen's (1991) Theory of Planned Behaviour (Armitage \& Conner, 2001; Conner \& Armitage, 1998) show that survey research can usefully inform predictions of behaviour. We therefore present our results with the qualification that studies that compare actual behaviour with values will more accurately measure the relationship. Indeed, others in our Lincoln tourism research team are currently researching links between awareness of ecolabels and actual behaviour (Reiser and Simmons, n.d.). This complementary research is concerned with what visitors actually do, whereas our research objectives involve investigation of the necessary dimension of preferences and dispositions of visitors and the ecolabel issue. In this research we concede some respondents may change their mind, some may not have the opportunity to act as they intend and that some may simply answer strategically. We nevertheless expect, for the most part, most respondents will act as they have indicated given the opportunity in the near future and given similar circumstances.

Our questionnaire started with a definition of 'ecolabels' so we can hardly claim that the results are the product of unfiltered questions. We acknowledge that the questionnaire was framed in a way that focused on ecolabels. This was necessary to learn about the current state of thinking on this topic among visitors. Notwithstanding this particular framing, which all questionnaires have, it was still the case that visitors expressed definite views about ecolabels. It must be noted that many respondents still chose to say that they did not know about ecolabels. The sample is unlikely to suffer from self-selection bias, with those 
more interested in the subject being more willing to respond, because most participants did not have a high level of interest in ecolabels. As responses to the first question will show, most had not been at a place that had an ecolabel. Moreover, nearly all participants agreed to be interviewed without having detailed knowledge about the substance of the questionnaire, other than that it was about environmental and cultural factors relating to tourism.

We are confident that our results reflect accurately what visitors say and think about ecolabels, and give an indication of actual behaviours. The research design is limited but still useful for documenting awareness of ecolabels among visitors to New Zealand.

\section{Results}

Cluster analysis using the simple K-means or quick cluster facility in SPSS was used to find two groups based on the manner in which they rated the eight questions about the relationship between humans and the environment. Respondents were asked to indicate their level of agreement or disagreement with each statement using a five-point scale from strongly disagree (1), unsure (3), to strongly agree (5). Table 2 reports the average score for each statement for each cluster and shows that $61 \%$ of respondents identified with Cluster 1 and $39 \%$ of respondents identified with Cluster 2.

Respondents loading onto Cluster 1 are those who express biocentric attitudes when asked about the environment. They agree that we are approaching the limit of the number of people that the earth can support, that when humans interfere with nature it often produces disastrous consequences, that humans are severely abusing the environment, and that plants and animals have as much right as humans to exist. Respondents loading onto Cluster 2 are those who express ambivalent environmental attitudes and they expressed neutral attitudes to all but one of the statements. They showed slight agreement with the idea that the earth has plenty of natural resources if we just learn to develop them. If, as demonstrated in alternative applications of the NEP scale, they had anthropocentric values, they would have more strongly agreed with three other statements. We have therefore labelled our second cluster as 'ambivalent'. These results do not fit our expectation from the environment values literature that visitors to New Zealand could be classified as having either biocentric or anthropocentric values. Instead it only found evidence for visitors with biocentric values. This finding may have resulted from the sample which was not from a general population but was mainly from international visitors to New Zealand who may very well be pro-nature in their outlook. Perhaps in our sample there is a continuum of sensitivity in attitude towards nature and it reflects the values of people who are biocentric or almost biocentric.

Demographic data were analysed for each cluster and some significant differences were found. For country of origin we used six regions and distinguished between those from the UK and those from elsewhere in Europe, because UK visitors are a major group visiting New Zealand. The biocentric cluster compared with the ambivalent cluster has more people from elsewhere in Europe ( $28 \%$ cf. $14 \%$ ) and more people from New Zealand (11\% cf. $7 \%$ ) (chi square $=11, \mathrm{df}=5, p=0.05$ ). In contrast, the ambivalent cluster compared to the 
Table 2 Average scores for environmental statements for each cluster

\begin{tabular}{|l|c|c|c||}
\hline & $\begin{array}{c}\text { Cluster 1 } \\
\text { Biocentric }\end{array}$ & $\begin{array}{c}\text { Cluster 2 } \\
\text { Ambivalen } \\
\boldsymbol{t}\end{array}$ & All Sample \\
\cline { 2 - 4 } & $\begin{array}{c}\mathbf{n}=\mathbf{1 7 7}, \\
\mathbf{6 1 \%}\end{array}$ & $\begin{array}{c}\mathbf{n}=\mathbf{1 1 3} \\
\mathbf{3 9 \%}\end{array}$ & $\begin{array}{c}\mathbf{2 9 0} \\
\mathbf{1 0 0 \%}\end{array}$ \\
\hline $\begin{array}{l}\text { We are approaching the limit of the number of } \\
\text { people that the earth can support. }\end{array}$ & 3.98 & 2.81 & 3.49 \\
\hline $\begin{array}{l}\text { Humans have the right to modify the natural } \\
\text { environment to suit their needs. }\end{array}$ & 2.25 & 3.28 & 2.65 \\
\hline $\begin{array}{l}\text { When humans interfere with nature it often } \\
\text { produces disastrous consequences. }\end{array}$ & 4.46 & 2.74 & 3.78 \\
\hline $\begin{array}{l}\text { Human ingenuity will ensure that we do not } \\
\text { make the earth unlivable. }\end{array}$ & 2.50 & 3.19 & 2.78 \\
\hline $\begin{array}{l}\text { Humans are severely abusing the environment. } \\
\text { The earth has plenty of natural resources if we }\end{array}$ & 3.44 & 2.78 & 3.79 \\
\hline just learn how to develop them. & 4.67 & 3.05 & 4.03 \\
\hline $\begin{array}{l}\text { Plants and animals have as much right as } \\
\text { humans to exist. }\end{array}$ & 1.70 & 3.27 & 2.32 \\
\hline $\begin{array}{l}\text { The balance of nature is strong enough to cope } \\
\text { with the impacts of modern industrial nations. }\end{array}$ & & 3.62 & 3.34 \\
\hline
\end{tabular}

biocentric cluster has more people from Australia (22\% cf. 17\%) and more people from the United Kingdom (30\% cf. 20\%). Income data using seven income ranges show that $38 \%$ of biocentric respondents earn $\$ 40,000$ or less annually compared with only $19 \%$ of ambivalent respondents (chi square $=15, \mathrm{df}=6, p=0.02$ ). There is no significant difference statistically between clusters in the proportions of men and women nor in average age (about 37 years). In terms of education level (secondary, technical/polytechnic or university), $62 \%$ of individuals expressing biocentric attitudes reported having a university education compared with only $42 \%$ of those expressing ambivalent environmental attitudes (chi square $=11$, $\mathrm{df}$ $=2, p=0.004$ ). Those respondents expressing ambivalent values were more likely to have had technical, polytechnic or secondary schooling. These results indicate that visitors in the biocentric cluster have lower incomes, tend to have a university education, and come from Europe and New Zealand.

In exploring visitors' attitudes to ecolabels we asked if they had been at any place in New Zealand, or in their travels to or from New Zealand, that had a tourism ecolabel. Over one-half (55\%) had not while $20 \%$ had and $35 \%$ were unsure. Differences were found between the biocentric and ambivalent clusters in response to this question on seeing or hearing of ecolabels. More biocentric respondents than ambivalent respondents ( $24 \%$ cf. $13 \%)$ indicated that they had been to a place with a tourism ecolabel (chi square $=12.02, \mathrm{df}=2, p=0.002$ ). When respondents who had not been to any place with a tourism ecolabel were asked: 'Have you ever heard of any tourism ecolabel?' $62 \%$ had not, $13 \%$ had and 25\% 
were unsure. Biocentric respondents were more likely than ambivalent respondents to respond affirmatively $(19 \% \mathrm{cf} .5 \%)($ chi square $=26.80, \mathrm{df}=2, p=0.001)$. Clearly, biocentric respondents were more likely than ambivalent respondents to report recalling exposure to tourism ecolabels but the majority of respondents reported that they have not been to a place with them nor had heard of tourism ecolabels. However, combining the proportion who had been to a place with an ecolabel with those who had heard of an ecolabel yields a total of $33 \%$ who have had some experience of ecolabels.

We designed the questionnaire to examine the possibility that if visitors considered New Zealand to be clean and green, especially given Tourism New Zealand's ' $100 \%$ pure' international marketing campaign, they might think there was little point in using ecolabels. If this were the case then interest in ecolabels would be low. Respondents were asked: 'Is New Zealand "clean" and "green"?' with responses taken on a Likert scale using a five-point agreement scale from -2 to 2 . Overall, $67 \%$ agreed and biocentric respondents were more likely than ambivalent respondents to strongly agree that New Zealand is 'clean and green' (mean of 1.23 cf. 0.62 ) (T-test $p=0.001$ ): $47 \%$ of ambivalent respondents indicated that they neither agreed nor disagreed with the 'clean and green' status of New Zealand. The 197 respondents who agreed that New Zealand is 'clean and green' were asked: 'Is tourism compatible with New Zealand's 'clean and green' image?'; $85 \%$ of biocentric respondents and $63 \%$ of ambivalent respondents agreed that tourism and the 'clean and green' image were compatible (chi square $11.62, \mathrm{df}=2, p=0.003)$. Overall, visitors agreed with the clean and green image of New Zealand and did not see any threat to New Zealand's clean and green image from tourism.

Respondents were asked whether ecolabelling needs to be used in New Zealand or whether it was not necessary for New Zealand. Overall, $72 \%$ of respondents agreed with the first option, while $84 \%$ of biocentric respondents indicated that ecolabelling was needed compared with $53 \%$ of ambivalent respondents (chi square $=31.53, \mathrm{df}=2, p=0.001$ ). We recorded open-ended comments on this question. Twenty-eight respondents (19 biocentric, nine ambivalent) said that they believed ecolabels would protect New Zealand's clean and green image. Twenty-three respondents (19 biocentric, four ambivalent) said that they believed that ecolabels would provide a choice for visitors, allowing them to choose more environmentally friendly operations or businesses. Twenty-three respondents (19 biocentric, four ambivalent) believed ecolabels were needed to raise awareness and educate people. In addition, 19 respondents (all biocentric) felt that ecolabels would help protect the environment.

Respondents were also asked: 'When considering your accommodation, would the presence of an ecolabel encourage you to stay there?' Biocentric respondents were more likely than ambivalent respondents (58\% cf. $19 \%$ ) to indicate that the presence of an ecolabel would encourage them to select a place of accommodation (chi square 44.3, $\mathrm{df}=2, p=0.001$ ). Biocentric respondents indicated that they would be willing to pay an average of $7.2 \%$ more $($ std dev $=8.06)$ for accommodation with an ecolabel compared with ambivalent respondents who indicated they would pay an average of $3.4 \%$ more $(\operatorname{std} \operatorname{dev}=6.23)(\mathrm{T}$-test $p$ $=0.0001$ ). 
Respondents were asked an open-ended question about what kind of information they wanted from an ecolabel. The three most frequent responses were certification details, recycling information and information on what was being done to protect the environment. Respondents from both groups (46 biocentric and 16 ambivalent respondents) were interested in the certification details for the ecolabel. More specifically, the respondents wanted to know who issued the label, if it was an internationally recognised certification body, what criteria had to be met by a businesses or organisation for it to be certified, and if the certificated businesses or organisations were monitored or reviewed annually to ensure that they continued to meet the ecolabel standards. Some respondents (21 biocentric and six ambivalent respondents) indicated that they were interested in information on recycling. Twenty-one biocentric and four ambivalent respondents indicated that they would like information about what the business or organisation does to protect the environment.

Respondents were then asked to use a 10-point scale (where 10 was highly important) to rate how important to them it was that any business or organisations' environmental standards (ecolabels) are certified. Overall, the score was 7.36 and biocentric respondents reported a mean sore of 7.92 compared with ambivalent respondents who placed less importance on the issue with a mean of 6.53 (T-test $p=0.001$ ). Generally then, visitors saw certification as important.

Other data relate to environmental behaviours as indicated by responses to two questions. Respondents were asked if they were personally a member of any environment organisation or group. Overall, there were 57 or $20 \%$ of respondents who so belonged, but of these most $(91 \%)$ were biocentric. Looking at each group, $29 \%$ of biocentric visitors belonged to an environment organisation or group while only $4 \%$ of ambivalent visitors so belonged. A second question asked if respondents would participate in a tree planting scheme where they would pay $\$ 15$ for planting a tree to offset some of the greenhouse gas emissions produced as a result of their travel. Overall, nearly one-half of respondents (43\%) said they would participate while $25 \%$ said no and $32 \%$ were unsure. Significantly more biocentric visitors than ambivalent visitors supported this scheme $(56 \%$ cf. $23 \%)$ (chi square $=31, \mathrm{df}=2, p=0.0001)$.

Another question asked for level of agreement with five tourism environment statements, scored on a Likert type five-point scale $(1=$ strongly disagree, $3=$ unsure and $5=$ strongly agree). Table 3 shows that both biocentric and ambivalent visitors have similar views for two of the statements. Both slightly agree that it is easier to be environmentally friendly at home, and both are neutral about the balance of concern between costs of products and services compared with their negative environmental impacts. The table also shows that there are statistically significant differences between the two clusters. Biocentric visitors are more likely to believe that their kind of travel does not harm the environment very much and they disagree with the idea of not worrying about the environment. That is, they do worry about the environment while travelling. Biocentric visitors state that they are prepared to spend more on travel products or services if it meant that they would have less negative impact on the environment, while ambivalent visitor are unsure. 
Table 3 Responses to tourism environment statements

\begin{tabular}{|c|c|c|c|c|}
\hline & & Biocentric & Ambivalent & Total \\
\hline \multirow{3}{*}{$\begin{array}{l}\text { The kind of travel I do does not harm the } \\
\text { environment very much. }\end{array}$} & Mean & $3.47^{*}$ & $3.17^{*}$ & 3.35 \\
\hline & Std Dev & 1.18 & 1.03 & 1.13 \\
\hline & $n$ & 177 & 112 & 294 \\
\hline \multirow{3}{*}{$\begin{array}{l}\text { I find it easier to practise } \\
\text { 'environmentally friendly' behaviours at } \\
\text { home than when I am travelling. }\end{array}$} & Mean & 3.30 & 3.27 & 3.28 \\
\hline & Std Dev & 1.33 & 0.89 & 1.17 \\
\hline & $n$ & 176 & 113 & 294 \\
\hline \multirow{3}{*}{$\begin{array}{l}\text { When I am travelling I am more } \\
\text { concerned about the cost of products and } \\
\text { services than I am about their negative } \\
\text { environmental impact. }\end{array}$} & Mean & 2.94 & 3.08 & 3.00 \\
\hline & Std Dev & 1.27 & 1.27 & 1.20 \\
\hline & $n$ & 177 & 112 & 294 \\
\hline \multirow{3}{*}{$\begin{array}{l}\text { When I am travelling I don't feel about } \\
\text { worrying about the environment. }\end{array}$} & Mean & $1.98^{* *}$ & $3.16^{* *}$ & 2.44 \\
\hline & Std Dev & 1.04 & 1.05 & 1.19 \\
\hline & $n$ & 177 & 113 & 295 \\
\hline \multirow{3}{*}{$\begin{array}{l}\text { I would be prepared to pay more on } \\
\text { travel products and services if it meant } \\
\text { that they would have less negative } \\
\text { impact on the environment. }\end{array}$} & Mean & $3.94^{* *}$ & $2.91^{* *}$ & 3.53 \\
\hline & Std Dev & 0.94 & 0.97 & 1.08 \\
\hline & & 176 & 112 & 293 \\
\hline
\end{tabular}

** T-test $p<0.001 ;{ }^{*}$ T-test $p<0.05$

\section{Discussion}

This study sought to document environmental values among mainly international visitors to Christchurch, New Zealand, to see if they are linked to awareness of and attitudes towards ecolabels. Accordingly, the study was designed on the expectation that visitors to New Zealand could be identified as having either biocentric or anthropocentric environmental values. The first point of discussion is the finding that in this case we found clear evidence of biocentric values only but not anthropocentric values. This finding may be due to the fact that few visitors have an exploitative view of the environment, which is a finding that might be expected of visitors coming to New Zealand, a destination typically marketed as having good environmental management. Consequently, while those in a group we have labelled as ambivalent may not go so far as to express biocentric values they nevertheless do not go so far as expressing anthropocentric values. However, such an interpretation is at odds with international studies of visitors which have found anthropocentric values (e.g. Ryan \& Harvey, 2000) or a New Zealand study of ecotourists which reported 'limits to growth', 'balance of nature' and a 'humans over nature' factors or general views of the natural environment (Higham et al., 2001). The biocentric visitors were more likely to be from New Zealand or Europe excluding the UK, have a university education and have lower incomes than ambivalent visitors. Perhaps this profile is consistent with a green visitor who is sensitive to the environment, aware of environmental issues, and perhaps not strongly business or income oriented. 
Our results were based on a sample of good size but not a good match to the known characteristics of the visitor population. It included mainly international visitors rather than local visitors but did include all of the main countries of origin for international visitors. The sample is not good for making precise estimates of characteristics of the population but it is useful for examining dominant characteristics and for exploring relationships between environment values and attitudes to ecolabels.

This research also sought to assess the level of awareness of and interest in ecolabels. The results show that there was modest level of awareness of ecolabels: $33 \%$ of visitors have either seen or heard about them. However, a majority of the sample had not been to any place with an ecolabel. Thus, despite the presence of many ecolabels overseas, and the emergence of some in New Zealand, there is little experience of them among visitors to New Zealand. The finding of low levels of awareness of ecolabels in the face of recent developments and use of ecolabels may be because these developments are new in New Zealand. For example, Kaikoura is one of two destination areas worldwide which has achieved Green Globe 21 benchmarking. However, it has not yet got to the point of advertising this status and consequently visitors to Kaikoura are unlikely to be aware of it. Many of the visitors interviewed travel in a circuit that includes Kaikoura. In fact, one Kaikoura business was the one most frequently stated when we asked respondents to identify the ecolabel. The finding of low levels of awareness of ecolabels may also be due to their low visibility outside New Zealand. Our question on awareness of ecolabels specified travel both within, and to or from New Zealand, so the potential contact with ecolabels should be higher than what is available in New Zealand, assuming that visitors travelling to New Zealand also travel in other places. In any case, for the visitors interviewed in this study, most of whom were from overseas, experience of ecolabels was modest.

Biocentric visitors appear to display consistently positive attitudes towards the environment. Despite limited initial awareness of ecolabels, the concept interested them and they felt it was important that ecolabels should be used in New Zealand and that the labels should be certified. They indicated that they would select accommodation with an ecolabel and would be more willing to pay a premium for ecolabel accommodation. Biocentric visitors also said that they wanted businesses to operate in environmentally friendly ways and that it was important for the environment standards of tourism businesses to be certified. They were more likely than their ambivalent counterparts to feel that New Zealand's environment was 'clean and green', and many of those who believed it was 'clean and green' thought that tourism was compatible with that image. New Zealand's clean and green image does not diminish interest in, or need for, ecolabels. In terms of behaviour, nearly one-third of biocentric visitors belong to an environmental organisation and most would plant a tree to offset greenhouse gas emissions. Biocentric visitors were more likely than ambivalent visitors to believe that their travel did not harm the environment, to report that they worried about the effects of their travel and that they would spend more to reduce environment impacts of their travel.

The development of ecolabels raised the question of why there is concern among visitors for the environment in which they travel and lack of response to 
ecolabels. Our approach to this anomaly was to examine visitors' environment values. We expected to find both biocentric and anthropocentric values and that identifying these would help us understand visitors' response to ecolabels. We did find different value clusters, but not an anthropocentric one, and these clusters were useful. The anomaly may exist because ecolabels are poorly promoted, and this interpretation is supported by our results which show that visitors are very interested in ecolabels but do not see them. Our results also rebut the argument that visitors are not concerned for the environment in which they travel.

The question of the match between attitude and behaviour is important and only partially addressed by the results presented here. The visitors appear to behave in ways that minimise harm to the environment as judged by their statements about travel behaviours. It appears that if ecolabels were in widespread use then they would use them and adopt discriminating behaviours. However, until there is widespread use of ecolabels we cannot assess what their actual behaviour would be in such settings. This problem can be overcome using quasi-experimental research designs in which non-randomised treatment groups are provided with ecolabels and observed in order to assess behavioural effects, and preliminary results of such work (Reiser \& Simmons, n.d.) show that visitors do not use ecolabels when making decisions about accommodation. Confirmation of these findings would suggest that visitors may well express concern about the environment in which they travel and show interest in ecolabels because they wish to avoid the reality that their activities have an adverse effect on the environment. In this view, their concern about the environment is a rationalisation for their activities.

There are clear policy implications from these results. The visitors interviewed were either biocentric or ambivalent, with the former in the majority and holding strong environment views. The visitors appear to be compatible with much of the tourism that New Zealand offers and if tourism develops further then making progress with ecolabels is compatible with international visitors. It may well be that ecolabelling becomes the norm for ecotourists even if there remains an imperfect fit between expressed preference and actual behaviours. Further, since the majority of visitors currently believe that tourism and New Zealand's 'clean and green' image are compatible and that nearly three-quarters agreed that ecolabels should be used, then the provision of ecolabels would be compatible with their decision to visit New Zealand and their expectations relating to travel in New Zealand. At present there are few ecolabels in place and the results presented here suggest that their development and promotion would be acceptable to visitors.

Ecolabelling initiatives will require paying attention to visitors' demand for ecolabels and, in particular, that they target different types of visitors, a point emphasised by Sharpley (2001: 52). If ecolabels were used by visitors then this should encourage businesses to adopt environmentally friendly practices. Such behaviours may outweigh the costs of certification. Independently of the promotion of ecolabels it remains the case that environmental standards need to be maintained and improved to satisfy visitors' expectations. If environmental quality begins to degrade then these environmentally sensitive visitors are likely to find New Zealand a less appealing destination.

Finally, the fact that tourism businesses, both internationally and in New 
Zealand, are beginning to use ecolabels but visitors are unaware of them raises a question about what is driving the development of ecolabels. Is it business promotion of ecolabels or visitor demand (market pull) or perhaps both factors at work? Font (2001) and Dann (1997) suggest that ecolabels are a product of businesses seeking a point of differentiation and certifying agencies pushing their label rather than market demand. Recent publicity in Christchurch about Green Globe developments certainly illustrates the enthusiasm that certifying agencies have for ecolabels (The Press, 5 March 2004). Our results show market demand but the low level of awareness among visitors in the presence of some ecolabels in New Zealand suggests that the other factors are major forces in the development of ecolabels.

\section{Conclusion}

The evidence presented supports the presence of the green visitor in New Zealand. The results suggest that many visitors will favourably receive ecolabel development in New Zealand and that ecolabel development and use should be supported. It may take some time before an effective system of labelling with international standards is well known among visitors. However, it is clear the current visitors already approve of the concept of ecolabelling. This means that the tourism industry should recognise and respond to the biocentric visitor by encouraging more environment friendly practices and their certification through ecolabels.

Some limitations to this research remain. We do not know with any certainty if the results found here apply to domestic visitors and since this group are about one-half the visitors to many destinations in New Zealand it is important to find out if their values and expectations of tourism are similar to the international visitors studied here. A more general question relates to the anthropocentric type found in many other studies. Where might anthropocentric visitors predominate and what are their views about ecolabels? There needs to be continued research on the ecolabels needs of visitors so that while operators and certifiers may continue to develop the use of ecolabels, this is done in ways that are sensitive to the needs of visitors and actually promote environment friendly behaviour. Further work is required on actual visitor behaviours in response to ecolabels. Despite the positive responses to ecolabels reported here, these responses do not necessarily translate to appropriate behaviours and we expect that the tension between expressed preferences and behaviours will remain a concern in the future even if ecolabels continue to be developed and adopted by tourism businesses.

\section{Acknowledgements}

Funding for this research was received from the Foundation for Research, Science and Technology. Axel Reiser and Dr Susanne Becken gave helpful comments on an earlier version of this paper. The author is grateful for the careful and detailed comments provided by four referees. Dr Andrew Cook provided help with some supplementary analysis of the data and provided a detailed review of the present version of this paper. 


\section{Correspondence}

Any correspondence should be directed to John R. Fairweather, Agribusiness and Economics Research Unit, P.O. Box 84, Lincoln University, Canterbury, New Zealand (Fairweat@lincoln.ac.nz).

\section{References}

Ajzen, I. (1991) The theory of planned behavior. Organisatonal Behavior and Human Decision Processes 50, 179-211.

Armitage, C.J. and Conner, M. (2001) Efficacy of the theory of planned behaviour: A meta-analytic review. British Journal of Social Psychology 40, 471-99.

Becken, S. (2002). Analysing international tourist flows to estimate energy use associated with air travel. Journal of Sustainable Tourism 10 (2), 114-31.

Beckmann, S.C. (1999) Ecology and consumption. In P.E. Earl and S. Kemp (eds) The Elgar companion to consumer research and economic psychology (pp. 170-75). Cheltenham: Edward Elgar.

Bergin, S. and Jago, L.K. (1999) Accreditation of adventure tourism operators: The consumer perspective. In J. Molloy and J. Davies (eds) Tourism and Hospitality Delighting the Senses 1999 Part II (pp. 305-16). Proceedings of the Ninth Australian Tourism and Hospitality Research Conference, CAUTHE, Adelaide.

Buckley, R.C. (2001) Turnover and trends on tourism ecolabels. In X. Font and R.C. Buckley (eds) Tourism Ecolabelling: Certification and Promotion of Sustainable Development (pp. 189-212). Wallingford: CABI.

Conner, M. and Armitage, C.J. (1998) Extending the theory of planned behaviour: A review and avenues for further research. Journal of Applied Social Psychology 28 (15), 1429-64.

Cook S.D., Stewart, E. and Repass, K. (1992) Discover America: Tourism and the Environment. Washington, DC: Travel Industry Association of America.

Dann, G.M.S. (1997) Greenspeak: An analysis of the language of eco-tourism. In C. Cooper and S. Wanhill Tourism Development: Environmental and Community Issues (pp. 91-101). Chichester: Wiley.

Dunlap, R.E., Van Liere, K.D., Mertig, A.G., and Jones, R.E. (2000) Measuring endorsement of the new ecological paradigm: A revised NEP scale. Journal of Social Issues 56 (3), $425-442$.

Font, X. (2001) Regulating the green message: The players in ecolabelling. In X. Font and R.C. Buckley (eds) Tourism Ecolabelling: Certification and Promotion of Sustainable Management (pp. 1-17). Wallingford: CABI.

Font, X. (2002) Environmental certification in tourism and hospitality: Progress, process and prospects. Tourism Management 23, 197-205.

Hamele, H. (2002) Ecolabels for tourism in Europe: Moving the market toward more sustainable practices. In M. Honey (ed.) Ecotourism and Certification: Setting Standards in Practice (pp. 187-210). Washington, DC: Island.

Higham, J., Carr, C. and Gael, S. (2001) Ecotourism in New Zealand: Profiling Visitors to New Zealand Ecotourism Operations. Department of Tourism Research Paper No. 10. Dunedin: University of Otago.

Honey, M. (2002) Conclusion. In M. Honey (ed.) Ecotourism and Certification: Setting Standards in Practice (pp. 357-71). Washington: Island.

Honey, M. and Stewart, E. (2002) Introduction. In M. Honey (ed.) Ecotourism and Certification: Setting Standards in Practice (pp. 1-29). Washington, DC: Island.

Issvardis, J-P. (2001) The pursuit of excellence: Benchmarking, accreditation, best practice and auditing. In D.B. Weaver (ed.) The Encyclopedia of Ecotourism. (pp. 579-94). Wallingford: CABI.

Khan, M. (2003) ECOSERV: Ecotourists' Quality Expectations. Annals of Tourism Research 30 (1), 109-24.

La Piere, R.T. (1934) Attitudes vs actions. Social Forces 13, 230-37.

Lubbert, C. (2001) Tourism ecolabels market research in Germany. In X. Font and R.C. 
Buckley (eds) Tourism Ecolabelling: Certification and Promotion of Sustainable Development (pp. 71-85). Wallingford: CABI.

Luzar, E.J., Diagne, A., Gan, C., Henning, B. (1995) Evaluating nature-based tourism using the new environment paradigm. Journal of Agricultural and applied Economics 27 (2), 544-55.

McArthur, S. (1997) Introducing the National Ecotourism Accreditation Program. Australian Parks and Recreation 33 (2), 30-34.

McFarlane, B.L. and Boxall, P.C. (2000) Factor influencing forest values and attitudes of two stakeholder groups: The case of the Foothills Model forest, Alberta, Canada. Society and Natural Resources 13, 649-61.

Nielson, N., Birtles, A. and Sofield, T. (1995) Ecotourism accreditation: Shouldn't the tourists have a say? In H. Richins and A. Crabtree (eds) Ecotourism and Nature-based Tourism: Taking the Next Steps (pp. 235-42). Proceedings of the Ecotourism Association of Australia National Conference, EAA, Brisbane.

Reiser, A and Simmons, D. (under review) A quasi-experimental method for testing the effectiveness of ecolabel promotion. Journal of Sustainable Tourism.

Ryan, C. and Harvey, K. (2000) Who likes saltwater crocodiles? Analysing sociodemographics of those viewing tourist wildlife attractions based on saltwater crocodiles. Journal of Sustainable Tourism 8 (5), 426-33.

Sharpley, R. (2001) The consumer behaviour context of ecolabelling. In X. Font and R.C. Buckley (eds) Tourism Ecolabelling: Certification and Promotion of Sustainable Management (pp. 41-55). Wallingford: CABI.

Simmons D.G., (1999) Eco-tourism: product or process. Paper given at Maanaki Whenua (Cherishing the Land) Conference, Wellington, April. On WWW at http:/ / www. landcare.cri.nz / conferences / manaakiwhenua/ papers / index.shtml?simmons.

Simmons, D.G., Fairweather, J.R. and Shone, M.C. (2003) Tourism in Christchurch and Akaroa: Challenges for Planning and Recommendations for Management. Report No. 39, Tourism Recreation Research and Education Centre (TRREC), Lincoln University.

Spittler, R. and Haak, U. (2001) Quality analysis of tourism ecolabels. In X. Font and R.C. Buckley (eds) Tourism Ecolabelling: Certification and Promotion of Sustainable Management (pp. 213-45). Wallingford: CABI.

Synergy (2000) Tourism Certification. A report by Synergy for WWF-UK.

The Press (2004). New Zealand urged to dazzle tourists. (5 March). P A6. Christchurch.

Vaske, J.J. and Donelly, M.P. (1999) A value-atttide-behavior model predicting wildland preservation voting intentions. Society and Natural Resources 12, 523-37.

Wicker, A.W. (1969) Attitudes versus actions: The relationship of verbal and overt behavioural responses to attitude objects. Journal of Social Issues 25, 41-78.

Wight, P.A. (2001) Ecotourists. In D.B. Weaver (ed.) The Encyclopedia of Ecotourism (pp. 37-62). Wallingford: CABI.

Wood, M.E. and Halpenny E.A. (2001) Ecotourism certification and evaluation: progress and prospects. In X. Font and R.C. Buckley (eds) Tourism Ecolabelling: Certification and Promotion of Sustainable Development (pp. 121-40). Wallingford: CABI. 